\title{
Greenhouse Gas Reduction in Off-Season Cucumber Production by Improving Energy Efficiency: A Case Study from Punjab, Pakistan
}

\author{
Qamar Ali ${ }^{1,2 *}$, Muhammad Tariq Iqbal Khan ${ }^{3}$, Muhammad Ashfaq ${ }^{4}$ \\ ${ }^{1}$ Institute of Agricultural and Resource Economics, University of Agriculture, Faisalabad-38040, Pakistan \\ ${ }^{2}$ Department of Economics, Virtual University of Pakistan-Faisalabad Campus-38000, Pakistan \\ ${ }^{3}$ Department of Economics, Government Postgraduate College, Jaranwala-37200, Pakistan \\ ${ }^{4}$ Institute of Agricultural and Resource Economics, University of Agriculture, Faisalabad-38040, Pakistan
}

Received: 27 November 2016

Accepted: 30 December 2016

\begin{abstract}
Approximately 10 to $12 \%$ of GHG emissions come from the agricultural sector. Consumption of energy in agriculture is a source of GHG and it can be decreased by efficient utilization of energy inputs. Therefore, our present research calculated energy efficiencies (for technical, pure technical, and scale) and extent of GHG reduction after benchmarking an inefficient farm in off-season cucumber production in Punjab, Pakistan. Primary data were collected from 70 farmers with simple random sampling. Average technical efficiency (TE), pure technical efficiency (PTE), and scale efficiency (SE) were 0.77, 0.91, and 0.85 , respectively, while increasing (IRS) and constant (CRS) return to scale were observed in 46 and 24 farms, respectively. The decrease in total input energy was 33,908.00 $\mathrm{MJ} \mathrm{ha}^{-1}(14.14 \%)$ if inefficient farmers use the energy inputs according to recommendations. A large share of energy savings comes from fertilizers (63.66\%), followed by diesel (25.88\%), plastic (5.78\%), chemicals $(2.69 \%)$, water $(1.06 \%)$, labour $(0.50 \%)$, and machinery $(0.44 \%)$. Total GHG reduction was $1,004.68 \mathrm{~kg} \mathrm{CO}_{2}$ eq.ha- ${ }^{-1}(17.75 \%)$ after improvement in energy efficiency. Agricultural extension staff should visit the vegetable farms on a regular basis and give necessary information about efficient utilization of energy inputs. In addition, the government should promote renewable sources of energy due to their environmentally friendly behavior.
\end{abstract}

Keywords: benchmarking, energy efficiency, environment, tunnel farming, vegetables

\section{Introduction}

There exists a decrease in fertile lands due to rapid increases in population, urbanization, and industrial areas, which highlights the importance of efficient utilization of scare resources - especially in the production of food.

*e-mail: qamarali2402@gmail.com
Food security is a primary concern in developing countries [1]. Vegetables are inevitably part of the agricultural sector and these are useful for nutritional-level maintenance and resistance against diseases [2-3]. Unemployment, poverty, and malnutrition are major problems faced by developing countries, and the vegetable sector has the ability to tackle these problems in the shortest time period [4].

Another problem faced by the world is global warming. There is an increase in the temperature of the earth as 
a result of greenhouse gas (GHG) emissions [5]. The use of different agricultural inputs increases to meet increasing demand. Moreover, different types of energy inputs such as petroleum, diesel, or other fuels are also required in the production of agricultural crops. But the use of energy inputs also emits GHG into the atmosphere [6].

Nearly 10 to $12 \%$ emissions of GHG come from the agriculture sector [7]. The contribution of the agricultural sector was $19.80 \%$ in gross domestic product of Pakistan, and it provides employment to $42.3 \%$ of the labor force [8]. In Pakistan, the area under vegetable production was 0.41 million ha of 23.40 million ha total cropped area [9]. GHG emissions decrease due to efficient use of energy inputs in agriculture [5]. Efficient energy utilization is needed for sustainable production in the agricultural sector due to decreases in environmental degradation [10].

Cucumber (Cucumis sativus L.) belongs to the Cucurbitaceae family with 118 genera and 825 species [11]. Its local name is khira and it is a primary component of salads [12]. It is a good source of vitamin C, niacin, calcium, iron, fibers, phosphorus, and thiamine. More than $50 \%$ of its production comes from Asia. Turkey, Iran, Uzbekistan, and Japan are important cucumber-producing countries [11].

Pakistan had 3,528 ha under cucumber cultivation in 2013-14 with 50,164 tons produced. The area under cucumber cultivation was 2,180 ha in 2004-05 for 28,179 tons. This shows $61.83 \%$ and $78.02 \%$ expansion in cultivation area and production, respectively, from 2004-05 to 2013-14. In Punjab, the area under cucumber cultivation was 1,767 ha with 39,436 tons produced in 2013-14, while the production area was 1,211 ha with 22,691 tons produced in 2004-05 [13-14], which shows a progressive increase in Pakistan.

The Punjab is situated between $24-37^{\circ} \mathrm{N}$ and $62-75^{\circ} \mathrm{E}$ in the fertile land of five rivers: the Indus, Jhelum, Chenab, Ravi, and Sutlej [15]. Its environment supports vegetable cultivation both in- and off-season. Off-season vegetables are cultivated in tunnel structure covered with a polythene sheet that controls the temperature and saves solar energy [9]. Tunnel farming area showed an increase in Pakistan because of more yield and expansion in the vegetable season [16].

Many researchers have used the data envelopment analysis (DEA) model for estimating agricultural sector efficiency. It is non-parametric and uses the technique of linear programming for producing frontier estimation in order to find relative efficiency of DMUs (decision making units) for many inputs and outputs [5]. Sueyoshi et al. [17] has highlighted the use of DEA in the field of energy and environment for four decades.

Literature shows the estimation of energy efficiency in the case of different crops like greenhouse tomato, tomato, wheat, greenhouse cucumber, and canola (in Iran and Poland) [1, 5-6, 10, 18-23]. But the literature about the reduction in GHG emissions due to energy efficiency was available for wheat and cucumber in Iran $[5,20]$ and wheat in Poland [23], but no research study was available about the estimation of energy efficiency in off-season cucumber production under a polythene sheet tunnel in Pakistan.

Monjezi et al. [1] found the energy efficiency in cucumber cultivation by using eight energy inputs: human power, fertilizers, diesel fuel, machinery, chemicals, seed, irrigation water, and electricity; and only one output. Mean technical, pure technical, and scale energy efficiencies were $88 \%, 91 \%$, and $96 \%$, respectively. Similarly, Pahlavan et al. [19] employed the DEA model to estimate efficiency in greenhouse cucumber cultivation in Iran. Mean value of TE, PTE, and SE were $0.83,0.95$, and 0.88 , respectively. Results show a $30.27 \%$ decrease in total input energy with changing the level of cucumber output by adopting the recommendations. Recently, Khoshnevisan et al. [20] explored the decrease in carbon emissions after energy efficiency improvement in cucumber cultivation in Iran. On average, total output and input energy was 151,846.2 $\mathrm{MJ} \mathrm{ha}^{-1}$ and 1,667,164.8 $\mathrm{MJ} \mathrm{ha}^{-1}$, respectively. Results explored a reduction of $24.46 \%$ (407916.3 $\mathrm{MJ} \mathrm{ha}^{-1}$ ) in total energy consumption as a result of the improvement in inefficient farms. After improving energy efficiency, total $\mathrm{CO}_{2}$ emission was $34,995.9 \mathrm{~kg}$ $\mathrm{CO}_{2}$ eq. ha ${ }^{-1}$ instead of $45,177.3 \mathrm{~kg} \mathrm{CO}$ eq. ha- ${ }^{-1}$.

Syp et al. [23] also employed data envelopment analysis for estimating energy efficiency in wheat production in Poland. Results showed that about 55\% of farms were operated efficiently. The score of technical efficiency for small inefficient farms (0.72) was less than medium (0.84) and large (0.84) farms. GHG emissions from $1 \mathrm{~kg}$ wheat production was more for medium farmers $(0.481 \mathrm{~kg}$ $\mathrm{CO}_{2}$ eq.), followed by small $\left(0.448 \mathrm{~kg} \mathrm{CO}_{2}\right.$ eq. $)$ and large ( $0.481 \mathrm{~kg} \mathrm{CO}$ eq.) farmers. GHG emission reduction was more for medium farmers $(29.0 \%)$, followed by large (28.6\%) and small (25.7\%) farmers.

As tunnel farming is a new technology and it is beneficial to investigate the energy use efficiency and chances of emission reduction in this activity. Therefore, our present study aims to continue the work on energy efficiency in the context of tunnel farming. The present study aims to explore energy efficiency in off-season cucumber production, reduction in energy consumption after benchmarking of inefficient farms, and reduction of greenhouse gas emissions due to efficient energy use.

\section{Experimental Section}

For empirical investigation of study objectives we employed simple random sampling for primary data collection from 70 farmers about the quantity of inputs and outputs in off-season cucumber cultivation in Punjab in 2014. Mian Shadi agricultural farm in Mamunkanjan, Faisalabad District, started off-season vegetable cultivation in Punjab. Kamalia in the Toba Tek Singh District is considered a hub of off-season vegetable cultivation in Punjab. Therefore, Faisalabad and Toba Tek Singh districts were selected for current study. The formula used for determining sample size [24] is expressed as: 


$$
n=\frac{N \times s^{2} \times t^{2}}{(N-1) d^{2}+s^{2} \times t^{2}}
$$

$\ldots$ where $\mathrm{n}$ indicates the sample size required, $\mathrm{N}$ denotes the number of holdings in the target population, $\mathrm{s}^{2}$ shows the variance of studied qualification in the population, $t$ is the $t$-value at $5 \%$ level of significance $(95 \%$ confidence limit; which was 1.96), and d shows the permissible or acceptable error $(5 \%)$. The required sample size was 67 off-season cucumber growers, but sample size increased to 70 for good results.

\section{Energy Input and Output}

Energy use from individual inputs in off-season cucumber production was calculated by multiplying the average amount of various inputs by their energy equivalents (Table 1). The value of energy from output and each input was recorded in $\mathrm{MJ} \mathrm{ha}^{-1}$.

\section{Greenhouse Gas Emissions}

Similarly, GHG emissions using different inputs was estimated by multiplying the quantity of different inputs with their GHG emission coefficient (Table 2).

\section{Data Envelopment Analysis (DEA)}

TE, PTE, and SE were determined by using the DEA method. With efficient production, a unit has the ability to get same quantity of output with fewer inputs (input-

Table 1. Energy equivalents of agricultural inputs and cucumber output.

\begin{tabular}{|c|c|c|c|}
\hline Energy source & Unit & $\begin{array}{c}\text { Energy } \\
\text { equivalent } \\
\left(\mathrm{MJ} \mathrm{unit}^{-1}\right)\end{array}$ & Reference \\
\hline \multicolumn{4}{|c|}{ Inputs } \\
\hline 1. Chemicals & $\mathrm{kg}$ & 101.2 & {$[25]$} \\
\hline 2. Labour & $\mathrm{h}$ & 1.96 & [26] \\
\hline 3. Machinery & $\mathrm{h}$ & 62.7 & [27] \\
\hline \multicolumn{4}{|l|}{ 4. Fertilizer } \\
\hline Nitrogen & $\mathrm{kg}$ & 66.14 & {$[25]$} \\
\hline Phosphorus & $\mathrm{kg}$ & 12.44 & {$[25]$} \\
\hline Potassium & $\mathrm{kg}$ & 11.15 & {$[25]$} \\
\hline Farmyard manure & $\mathrm{kg}$ & 0.3 & {$[28]$} \\
\hline 5. Seeds & $\mathrm{kg}$ & 1.00 & [27] \\
\hline 6. Water for irrigation & $\mathrm{m}^{3}$ & 0.63 & {$[25]$} \\
\hline 7. Diesel & 1 & 56.31 & {$[25]$} \\
\hline \multicolumn{4}{|c|}{ Output } \\
\hline Cucumber & $\mathrm{kg}$ & 0.8 & [29] \\
\hline
\end{tabular}

Table 2. Coefficients of GHG emissions for agricultural inputs.

\begin{tabular}{|c|c|c|c|}
\hline Inputs & Unit & $\begin{array}{l}\text { GHG coefficient } \\
\left(\mathrm{kg} \mathrm{CO}_{2} \text { eq. } \text { unit }^{-1}\right)\end{array}$ & Reference \\
\hline \multicolumn{4}{|c|}{ Inputs } \\
\hline 1. Chemicals & $\mathrm{Kg}$ & 2.47 & [30] \\
\hline 2. Machinery & MJ & 0.071 & [6] \\
\hline \multicolumn{4}{|l|}{ 3. Fertilizer } \\
\hline Nitrogen & $\mathrm{Kg}$ & 1.3 & [6] \\
\hline Phosphorus & $\mathrm{Kg}$ & 0.2 & [6] \\
\hline Potassium & $\mathrm{Kg}$ & 0.2 & [6] \\
\hline Farmyard manure & $\mathrm{Kg}$ & 0.126 & [31] \\
\hline 4. Diesel & $\mathrm{L}$ & 2.76 & [6] \\
\hline
\end{tabular}

oriented), or increase the quantity of output by using same level of inputs (output-oriented) [5]. The present study employed the input-oriented DEA approach due to the presence of many inputs and only one output.

Charnese Coopere Rhodes (CCR) and Bankere Charnese Cooper (BCC) are commonly used DEA models for efficiency studies. The production frontier in the case of the CCR model was spanned by the linear combination of available DMUs, while production frontier in the case of the BCC model was spanned by convex hull of available DMUs. CCR and BCC models used the assumption of constant (CRS) and variable (VRS) returns to scale, respectively. TE compares the existing production with maximum production potential for a DMU. TE $\left(\theta_{c}\right)$ is obtained by dividing the sum of weighted outputs by the sum of weighted inputs [5]:

$$
\theta_{j}=\frac{\sum_{r=1}^{n} u_{r} y_{r j}}{\sum_{s=1}^{m} u_{s} y_{s j}}
$$

... where $\theta_{j}$ depicts the TE score for unit $\mathrm{j} ; \mathrm{x}$ and $\mathrm{y}$ indicates the input and output, and $\mathrm{v}$ and $\mathrm{u}$ shows the weights of input and output, respectively; s reveals the number of inputs $(\mathrm{s}=1,2, \ldots, \mathrm{m}) ; \mathrm{r}$ represents the number of outputs $(r=1,2, \ldots, n)$; and $j$ describes jth DMUs $(j=1,2, \ldots, k)$. The input-oriented CCR model used for calculating the TE of a DMU is given below [5]:

$$
\begin{gathered}
\min \theta \\
\text { s.t.: } \\
Y \lambda \geq Y_{0} \\
\theta X_{0}-X \lambda \leq 0 \\
\lambda \geq 0
\end{gathered}
$$

$\ldots$ where $Y_{0}$ represents the $\mathrm{s} \times 1$ vector of the original output values and $X_{0}$ represents the $\mathrm{m} \times 1$ vector of original inputs used by the oth farm. $\mathrm{Y}$ indicates the $\mathrm{s} \times \mathrm{n}$ outputs matrix and $X$ reveals the $m \times n$ inputs matrix for all $n$ units used in the sample. $\lambda$ shows an $n \times 1$ vector of weights and $q$ describes a scalar having a value between 0 and 1 , which 
shows the value of efficiency for each DMU. $\theta$ represents the estimated TE of DMU. DMUo and $\lambda$ is the intensity of the efficient DMUs in projecting inefficient DMUs on the efficient frontier, also known as the convexity constant. The optimal efficiency $\theta$ will be less than or equal to 1 . DMUs having $\theta<1$ are inefficient and DMUs having $\theta=1$ made a boundary points set on the frontier [5].

Efficiency estimated by the CCR model has both the TE and SE. Therefore, the BCC model was developed by Banker et al. [32] and cited in Khoshnevisan et al. [5] for PTE estimation. It reveals that a change in inputs causes a disproportionate change in output. Generally, the PTE value is greater than TE value due to its more flexible nature and it envelops the data in a tight way. This provides a way for SE estimation for DMU as:

$$
S E=\frac{\theta_{C R S}}{\theta_{V R S}}
$$

When $\mathrm{SE}=1$ it denotes the scale efficiency (or CRS) and $\mathrm{SE}<1$ denotes scale inefficiency. Scale inefficiency of a DMU points out the presence of either increasing (IRS) or decreasing (DRS) returns to scale. However, the value of SE cannot explore the presence of IRS or DRS. For this, NIRS (non-increasing return of scale) is used in a DEA model. A comparison between efficiency score obtained from the BCC and NIRS models is made for the detection of IRS or DRS. If the efficiency scores from BCC and NIRS are equal, then it indicates the presence of DRS. Otherwise there exist IRS. The energy-saving target ratio (ESTR) determined the level of inefficiency for the use of energy inputs and it is expressed as [5]:

$$
E S T R_{j}=\frac{(\text { Energy saving target })_{j}}{(\text { Actual energy input })_{j}} \times 100
$$

...where reduction in total energy inputs without changing the level of output is called energy-saving target. Its percentage value lies between 0 and 100. A high value of ESTR shows higher inefficiency in the use of energy or higher savings in the use of energy. The data were analyzed using the DEA software EMS (efficiency measurement systems), SPSS-15, and Microsoft Excel.

\section{Results and Discussion}

\section{Energy Results}

Table 3 reveals the existing situation of energy utilization from different energy inputs and outputs in off-season cucumber cultivation. The concept of energy inefficiency was supported by large value of standard deviation in both inputs and outputs. It shows the possibility of improvement in the use of input energy in off-season cucumber cultivation. Energy inputs used in off-season cucumber production are plastic, seed, labour, farmyard manure, nitrogen, phosphorus, potassium, chemicals, machinery, diesel, and water. On average, total input energy was $239738.11\left(\mathrm{MJ} \mathrm{ha}^{-1}\right)$ while output energy was $245371.73\left(\mathrm{MJ} \mathrm{ha}^{-1}\right)$. These values shows the existing situation about input and output energy in the presence of energy ineffciency. Table 3 also shows the consumption of input energy after the recommended use of energy inputs.

\begin{tabular}{|c|c|c|c|c|c|}
\hline Input & $\begin{array}{l}\text { Present use } \\
\left(\mathrm{MJ} \mathrm{ha}^{-1}\right)\end{array}$ & $\begin{array}{l}\text { Standard } \\
\text { deviation }\end{array}$ & $\begin{array}{l}\text { Target use } \\
\left(\mathrm{MJ} \mathrm{ha}^{-1}\right)\end{array}$ & $\begin{array}{l}\text { Energy saving } \\
\quad\left(\mathrm{MJ} \mathrm{ha}^{-1}\right)\end{array}$ & $\begin{array}{c}\text { ESTR } \\
(\%)\end{array}$ \\
\hline 1. Plastic* (kg) & $82,976.66$ & $22,445.22$ & $81,018.31$ & $1,958.35$ & 2.36 \\
\hline 1. Seed (kg) & 0.38 & 0.05 & 0.36 & 0.02 & 6.11 \\
\hline 2. Labour (hours) & $6,788.05$ & $1,028.77$ & $6,619.19$ & 168.87 & 2.49 \\
\hline \multicolumn{6}{|l|}{ 3. Fertilizer (kg) } \\
\hline Nitrogen & $64,905.97$ & $29,079.17$ & $45,925.58$ & $18,980.39$ & 29.24 \\
\hline Phosphorus & $8,604.44$ & $4,232.84$ & $6,562.95$ & $2,041.49$ & 23.73 \\
\hline Potassium & $1,160.14$ & $1,008.84$ & 821.25 & 338.89 & 29.21 \\
\hline Farmyard manure & $2,764.05$ & $2,019.05$ & $2,539.22$ & 224.83 & 8.13 \\
\hline 4. Chemicals (kg) & $11,755.53$ & $3,422.54$ & $10,842.99$ & 912.54 & 7.76 \\
\hline 5. Machinery (hours) & $5,946.71$ & $2,551.49$ & $5,797.89$ & 148.82 & 2.50 \\
\hline 6. Diesel (1) & $48,074.55$ & $15,503.18$ & $39,299.40$ & $8,775.16$ & 18.25 \\
\hline 7. Water $\left(\mathrm{m}^{3}\right)$ & 6761.62 & 1411.63 & $6,402.97$ & 358.65 & 5.30 \\
\hline Total Input energy (MJ ha-1) & $239,738.11$ & $59,940.03$ & $205,830.11$ & $33,908.00$ & 14.14 \\
\hline Total output energy (MJ ha-1) & $245,371.73$ & $63,171.13$ & \multicolumn{3}{|c|}{ No change in input oriented DEA } \\
\hline
\end{tabular}

Table 3. Energy savings ( $\left.\mathrm{MJ} \mathrm{ha}^{-1}\right)$ according to study recommendations.

*Polythene sheet and mulch sheet 
But it is better to discuss the energy-saving part of Table 3 after estimating energy efficiency and benchmarking.

\section{DEA Results}

\section{Benchmarking}

Benchmarking is a comparison between the performance of an individual production unit and its nearest best possible production unit within the same group. Benchmarking used the TE score from the BCC or VRS DEA models [5]. Table 4 describes the technical efficiency score for 14 selected DMUs. Out of 70 DMUs, 35 were found technically efficient while 35 DMUs showed inefficiency in the use of energy inputs. Benchmarking is a tool for inefficient DMUs to select the best possible combination of energy inputs to become an efficient DMU. Out of 14 selected DMUs, eight were technically efficient while the remaining six showed inefficiency. For example, DMU4 was inefficient due to TE $(0.6749<1)$. For best practices, DMU4 can use the composite DMU made by the combination of DMU15, DMU18, and DMU25. Benchmarking recommended that

Table 4. Results of technical efficiency and benchmarking.

\begin{tabular}{|c|c|c|c|}
\hline DMU & TE (\%) & $\begin{array}{l}\text { Frequency in } \\
\text { reference set }\end{array}$ & Benchmarks \\
\hline 1 & 100 & 20 & \\
\hline 2 & 100 & 0 & \\
\hline 3 & 100 & 4 & \\
\hline 4 & 67.49 & • & $\begin{array}{c}15(0.20) 18(0.67) 25 \\
(0.13)\end{array}$ \\
\hline 5 & 82.18 & & $\begin{array}{c}3(0.07) 8(0.12) 11 \\
(0.24) 15(0.21) 18 \\
(0.10) 22(0.26)\end{array}$ \\
\hline 6 & 100 & 0 & . \\
\hline . & . & . & . \\
\hline 14 & 100 & 28 & \\
\hline 15 & 100 & 24 & $\cdot$ \\
\hline . & . & . & . \\
\hline 25 & 100 & 23 & \\
\hline . & . & . & . \\
\hline 66 & 100 & 5 & \\
\hline 67 & 77.86 & & $\begin{array}{c}3(0.16) 14(0.22) 25 \\
(0.51) 40(0.11)\end{array}$ \\
\hline 68 & 79.19 & & $\begin{array}{c}1(0.37) 14(0.44) 15 \\
(0.06) 25(0.13)\end{array}$ \\
\hline 69 & 84.79 & & $\begin{array}{c}1(0.37) 14(0.09) 18 \\
(0.10) 25(0.27) 40 \\
(0.17)\end{array}$ \\
\hline 70 & 77.98 & & $\begin{array}{c}1(0.12) 14(0.42) 15 \\
(0.34) 25(0.12)\end{array}$ \\
\hline
\end{tabular}

DMU4 should use 20\% input of DMU15, 67\% inputs of DMU18, and $13 \%$ inputs of DMU25 to achieve the best production frontier. DMU14 appeared 28 times in the benchmarking of inefficient DMUs, followed by DMU15 (24 times) and DMU 25 (23 times). According to the frequency of a DMU in the benchmarking, DMU14 and DMU15 were most efficient, followed by DMU25 and DMU1.

\section{Efficiency Estimates}

Energy efficiency score was determined with the help of the input-oriented DEA model. The TE and PTE scores were obtained by using the CCR and BCC models, respectively. Scale efficiency score was estimated by using efficiency scores from the CCR and BCC models. Frequency distribution of TE, PTE, and SE are depicted in Fig. 1. Thirty-fve (50 \%), 24 (34.29\%), and 24 (34.29\%) farmers were energy effcient with respect of PTE, SE, and TE, respectively. The efficiency range of remaining farmers is revealed by Fig. 1.

Table 5 reveals that the means of TE (CRS), PTE (VRS), and SE were $0.77,0.91$, and 0.85 , respectively. On average, TE value shows the chances of $23 \%$ less use of energy inputs in order to obtain the same output with the given technology if a farmer operates at a technically efficient level with respect to energy. Energy inefficiency was also found in agricultural crops as mentioned by Khoshnevisan et al. [5] for wheat in Iran. The score of energy efficiency was 0.77 for paddy [33], 0.94 for kiwifruit [34], 0.74 for canola [18], 0.82 for tomato [10], 0.82 for wheat [5], and 0.68 for cucumber [20]. The difference in efficiency score rises when the farmers do not utilize the input resources according to recommendations. Some sources of inefficiency were less education, financial constraints, large area [35], and improper input utilization such as chemicals and fertilizers [36].

There exists a constant return to scale when efficiency scores from the CCR and BCC models are equal, which was also explored by Khoshnevisan et al. [5] in wheat

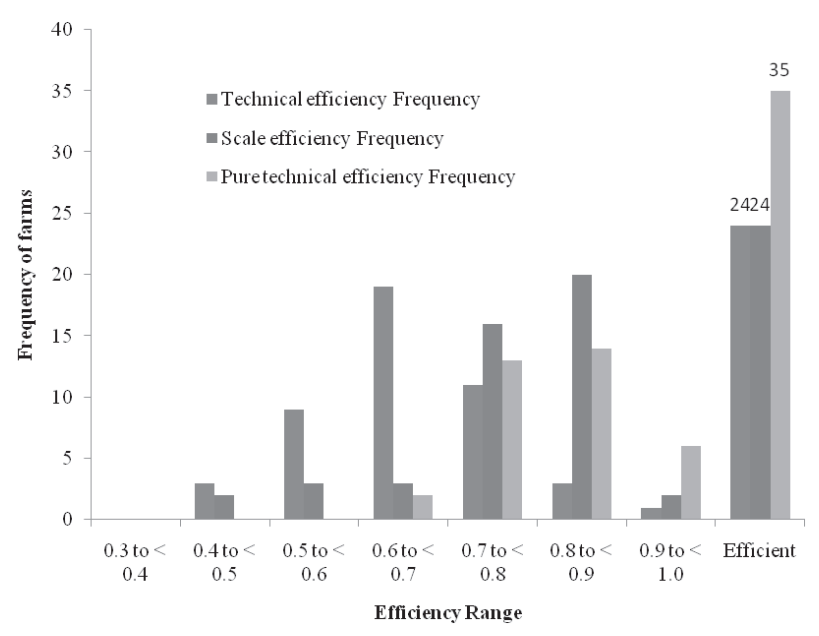

Fig. 1. Frequency distribution for off-season cucumber farmers. 
Table 5. Analysis of efficiency scores and returns to scale.

\begin{tabular}{|c|c|c|c|c|c|}
\hline \multirow{2}{*}{ DMU } & \multicolumn{3}{|c|}{$\mathrm{TE}$} & \multirow{2}{*}{$\mathrm{SE}$ (CRS/VRS) } & \multirow{2}{*}{ Return to scale } \\
\hline & CRS & VRS & NIRS & & \\
\hline 1 & 1.00 & 1.00 & 1.00 & 1.00 & CRS \\
\hline 2 & 0.46 & 1.00 & 0.46 & 0.46 & IRS \\
\hline 3 & 1.00 & 1.00 & 1.00 & 1.00 & CRS \\
\hline 4 & 0.53 & 0.67 & 0.53 & 0.79 & IRS \\
\hline 5 & 0.64 & 0.82 & 0.64 & 0.78 & IRS \\
\hline . & . & . & . & . & . \\
\hline . & . & . & . & . & . \\
\hline . & . & . & . & . & . \\
\hline 65 & 0.71 & 0.79 & 0.71 & 0.90 & IRS \\
\hline 66 & 1.00 & 1.00 & 1.00 & 1.00 & CRS \\
\hline 67 & 0.69 & 0.78 & 0.69 & 0.88 & IRS \\
\hline 68 & 0.66 & 0.79 & 0.66 & 0.84 & IRS \\
\hline 69 & 0.67 & 0.85 & 0.67 & 0.79 & IRS \\
\hline 70 & 0.62 & 0.78 & 0.62 & 0.79 & IRS \\
\hline Average & 0.77 & 0.91 & 0.77 & 0.85 & Total \\
\hline Maximum & 1.00 & 1.00 & 1.00 & 1.00 & $\mathrm{IRS}=46$ \\
\hline Minimum & 0.44 & 0.66 & 0.44 & 0.44 & $\mathrm{CRS}=24$ \\
\hline $\mathrm{SD}$ & 0.18 & 0.11 & 0.18 & 0.14 & $\mathrm{DRS}=00$ \\
\hline
\end{tabular}

production. Unequal energy efficiency scores from CCR and $\mathrm{BCC}$ models indicate the presence of variable returns to scale, but do not describe whether it is decreasing or increasing. For the detection of IRS or DRS, the DEA model with NIRS was applied. The NIRS model shows only DRS, and equal scores of TE from BCC and NIRS models indicate the presence of DRS for a DMU. Unequal scores of TE from BCC and NIRS models indicate IRS for DMU [5]. IRS and CRS were found in 46 and 24 off-season cucumber farms, respectively. IRS indicates the possibility of increasing output with the utilization of more energy inputs.

\section{Energy Saving from Different Energy Inputs}

Energy saving is the decrease in the use of energy inputs when all farmers operate at a technically efficient level. Table 3 represents the present and target (recommended) use of energy inputs for the reduction in energy consumption as well as greenhouse gas emissions. Table 3 shows the amount of energy saved after benchmarking according to the BCC model. The target consumption of input energy was 205,830.11 $\mathrm{MJ} \mathrm{ha}^{-1}$ when all DMUs were operating at energy efficient levels (after benchmarking). This indicates a 33,908.00 $\mathrm{MJ} \mathrm{ha}^{-1}(14.14 \%)$ decrease in energy inputs, while output and technology remain constant.
Khoshnevisan et al. [5] mentioned a 2.6\% decrease in total input energy due to improvement in energy efficiency in the case of wheat. The ESTR ratio in off-season cucumber production was maximum (29.24\%) for nitrogen followed by potassium $(29.21 \%)$, phosphorus $(23.73 \%)$, diesel (18.25\%), farmyard manure $(8.13 \%)$, chemicals $(7.76 \%)$, seeds $(6.11 \%)$, water $(5.30 \%)$, machinery $(2.50 \%)$, labour $(2.49 \%)$, and plastic $(2.36 \%)$. Energy saving was maximum from fuel consumption $(54 \%)$ in cucumber as explored by Monjezi et al. [1]. Maximum reduction in

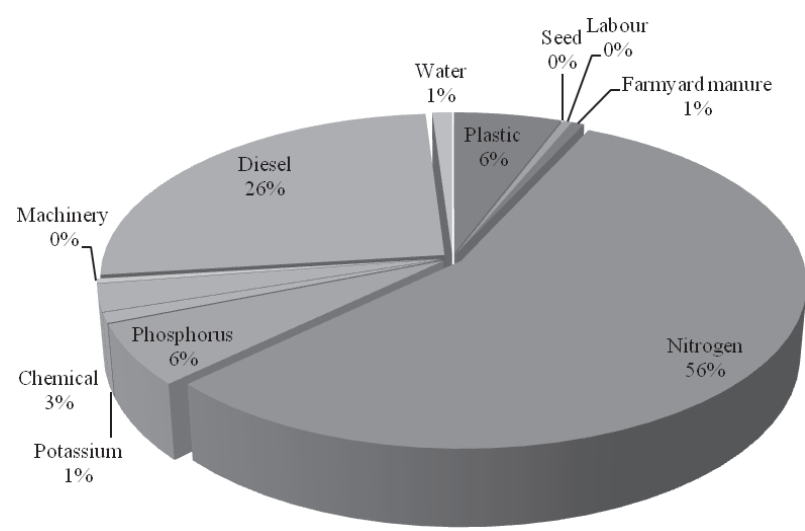

Fig. 2. Share of inputs in total energy savings in off-season cucumber production. 
Table 6. GHG emissions based on present and target energy inputs.

\begin{tabular}{|c|c|c|c|c|}
\hline \multirow{2}{*}{ Inputs } & \multicolumn{2}{|c|}{ GHG emission $\left(\mathrm{kg} \mathrm{CO}_{2}\right.$ eq.ha $\left.{ }^{-1}\right)$} & \multirow{2}{*}{ Decrease } & \multirow{2}{*}{ Decrease $(\%)$} \\
\hline & Present & Target & & \\
\hline 1. Chemicals (kg) & 286.92 & 264.65 & 22.27 & 7.76 \\
\hline 2. Machinery (MJ) & 422.22 & 411.65 & 10.57 & 2.50 \\
\hline \multicolumn{5}{|l|}{ 3. Fertilizer } \\
\hline Nitrogen $(\mathrm{kg})$ & $1,275.74$ & 902.68 & 373.06 & 29.24 \\
\hline Phosphorus (kg) & 138.78 & 105.51 & 33.27 & 23.97 \\
\hline Potassium (kg) & 20.81 & 14.73 & 6.08 & 29.21 \\
\hline Farmyard Manure (kg) & $1,160.90$ & $1,066.47$ & 94.43 & 8.13 \\
\hline 4. Diesel (l) & $2,356.34$ & $1,891.34$ & 465.00 & 19.73 \\
\hline Total GHG emission ( $\mathrm{kg} \mathrm{CO}_{2}$ eq.ha $\left.{ }^{-1}\right)$ & $5,661.71$ & $4,657.03$ & $1,004.68$ & 17.75 \\
\hline
\end{tabular}

the use of fertilizer was also found by Khoshnevisan et al. [5]. Plastic and labour were less disturbed factors as a result of improvements in efficiency, and it also supported the concept of employment generation in this sector. The decrease in total input energy was $25.15 \%$ in tomato [10], and $30.27 \%$ [19] and $32.39 \%$ [20] in greenhouse cucumber production. The percentage share of individual input in the reduction of total input energy is explored by Fig. 2, which is different from ESTR for each input because it compares the decrease in energy of a specific input as a percentage of total decrease in energy, while ESTR shows the percentage reduction in the energy of a specific input as compared to its initial use.

\section{GHG Reduction in Off-Season Cucumber Production}

Table 6 depicts the differences between GHG emissions for efficient and inefficient use of energy inputs. At present, total $\mathrm{GHG}$ emission was $5,661.71 \mathrm{~kg} \mathrm{CO}$ eq.ha ${ }^{-1}$, but it becomes $4,657.03 \mathrm{~kg} \mathrm{CO}$ eq.ha $^{-1}$ if all farms operate at an energy-efficient level. This shows the reduction of $1,004.68 \mathrm{~kg} \mathrm{CO}$ eq.ha-1 $(17.75 \%)$ in GHG emissions in off-season cucumber production due to energy-efficient farming (after benchmarking). The reduction in GHG emissions was more from fertilizers followed by diesel, chemicals, and machinery. The GHG emissions decrease was $1.48 \%$ in wheat [5].

\section{Conclusions}

The current study was conducted in Punjab, Pakistan, with the collection of primary data from 70 off-season cucumber farmers. Its primary objective was to calculate energy efficiency, which was further distinguished as TE, PTE, and SE with DEA. A decrease in the level of total input energy was estimated if all inefficient farmers followed the study recommendation (by benchmarking). A decrease in GHG emissions was found for recommended or target use of energy inputs. Technically efficient farmers were $34.29 \%$ (24 farmers) on the basis of the CCR model, while efficient farmers were $50 \%$ (35 farmers) on the basis of the BCC model. Mean values of TE, PTE, and SE were 0.77, 0.91, and 0.85, respectively, while IRS and CRS were observed in 46 and 24 farmers, respectively. Total input energy was reduced by $33,908.00 \mathrm{MJ} \mathrm{ha} \mathrm{h}^{-1}(14.14 \%)$ if inefficient farms used the energy inputs according to recommendations. A major portion of energy savings comes from fertilizers $(63.66 \%)$, followed by diesel $(25.88 \%)$, plastic $(5.78 \%)$, chemicals $(2.69 \%)$, water $(1.06 \%)$, labour $(0.50 \%)$, and machinery $(0.44 \%)$. Total greenhouse gas reduction was $1,004.68 \mathrm{~kg} \mathrm{CO}_{2}$ eq. $\mathrm{ha}^{-1}(17.75 \%)$ as a result of improvement in the efficiency of energy used in offseason cucumber production. The government should ensure the availability of agricultural extension staff and the provision of necessary information about efficient utilization of energy inputs. The government should create awareness of the use of renewable sources of energy to make the environment clean.

\section{Acknowledgements}

I acknowledge the cooperation of all respondents.

\section{References}

1. MONJEZI N., SHEIKHDAVOODI M.J., TAKI M. Energy use pattern and optimization of energy consumption for greenhouse cucumber production in Iran using data envelopment analysis (DEA). Modern Applied Science, 5 (6), 139, 2011.

2. OGUNNIYI L.T., OLADEJO J.A. Technical efficiency of tomato production in Oyo state Nigeria. Agricultural Science Research Journal, 1 (4), 84, 2011.

3. IBRAHIM H.Y., OMOTESHO O.A. Determinant of technical efficiency in vegetable production under Fadama in northern guinea savannah, Nigeria. Journal of Agricultural Technology, 9 (6), 1367, 2013. 
4. AKTER S., ISLAM M.S., RAHMAN M.S. An economic analysis of winter vegetables production in some selected areas of Narsingdi district. Journal of Bangladesh Agricultural University, 9 (2), 241, 2011.

5. KHOSHNEVISAN B., RAFIEE S., OMID M., MOUSAZADEH H. Applying data envelopment analysis approach to improve energy efficiency and reduce GHG (greenhouse gas) emission of wheat production. Energy, 58, 588, 2013a.

6. KHOSHNEVISAN B., SHARIATI H.M., RAFIEE S., MOUSAZADEH H. Comparison of energy consumption and GHG emissions of open field and greenhouse strawberry production. Renewable and Sustainable Energy Reviews, 29, 316, 2014.

7. PISHGAR-KOMLEH S.H., GHAHDERIJANI M., SEFEEDPARI P. Energy consumption and $\mathrm{CO}_{2}$ emissions analysis of potato production based on different farm size levels in Iran. Journal of Cleaner Production, 33, 183, 2012.

8. GOVERNMENT OF PAKISTAN. Economic survey of Pakistan 2015-16. Ministry of Finance, Islamabad, 2016a.

9. MUHAMMAD S.A., SAGHIR A., ASHRAF I., ASGHAR K., KOUSAR R. An impact assessment of tunnel technology transfer project in Punjab, Pakistan. World Applied Sciences Journal, 33 (1), 33, 2015.

10. PAHLAVAN R., OMID M., AKRAM A. Energy use efficiency in greenhouse tomato production in Iran. Energy, 36, 6714, 2011

11. KHAN Z., SHAH A.H., GUL R., MAJID A., KHAN U., AHMAD H. Morpho-agronomic characterization of cucumber germplasm for yield and yield associated traits. International Journal of Agronomy and Agricultural Research, 6 (1), 1, 2015.

12. MAURYA G.P., PAL V., SINGH G.P., MEENA L.K. An economic analysis of cucumber cultivation in Sultanpur District of Uttar Pradesh (India). International Journal of Agricultural Sciences and Research, 5 (1), 23, 2015.

13. GOVERNMENT OF PAKISTAN. Fruit, vegetables and condiments statistics of Pakistan 2008-09. Ministry of National Food Security \& Research, Islamabad, 2009.

14. GOVERNMENT OF PAKISTAN. Fruit, vegetables and condiments statistics of Pakistan 2014-15. Ministry of National Food Security \& Research, Islamabad, 2016b.

15. FAROOQI A., MASUDA H., FIRDOUS N. Toxic fluoride and arsenic contaminated groundwater in the Lahore and Kasur districts, Punjab, Pakistan and possible contaminant sources. Environmental Pollution, 145, 839, 2007.

16. IQBAL Q., AMJAD M., ASI M.R., ALI M.A., AHMAD R. Vegetative and reproductive evaluation of hot peppers under different plastic mulches in poly/plastic tunnel. Pakistan Journal of Agricultural Sciences, 46 (2), 113, 2009.

17. SUEYOSHI T., YUAN Y., GOTO M. A literature study for DEA applied to energy and environment. Energy Economics, in press, http://dx.doi.org/10.1016/j.eneco.2016.11.006

18. MOUSAVI-AVVAL S.H., RAFIEE S., JAFARI A., MOHAMMADI A. Improving energy use efficiency of canola production using data envelopment analysis (DEA) approach. Energy, 36, 2765, 2011.

19. PAHLAVAN R., OMID M., AKRAM A. Application of data envelopment analysis for performance assessment and energy efficiency improvement opportunities in greenhouses cucumber production. Journal of Agricultural Science and Technology, 14, 1465, 2012

20. KHOSHNEVISAN B., RAFIEE S., OMID M., MOUSAZADEH $\mathrm{H}$. Reduction of $\mathrm{CO}_{2}$ emission by improving energy use efficiency of greenhouse cucumber production using DEA approach. Energy, 55, 676, 2013b.
21. MOGHIMI M.R., ALASTI B.M., DRAFSHI M.A.H. Energy input-output and study on energy use efficiency for wheat production using DEA technique. International Journal of Agriculture and Crop Sciences, 5 (18), 2064, 2013.

22. RAHBARI H., MAHMOUDI A., AJABSHIRCHI Y. Improving energy use efficiency of greenhouse tomato production using data envelopment analysis (DEA) technique. International Journal of Agriculture: Research and Review, 3 (3), 559, 2013.

23. SYP A., FABER A., BORZĘCKA-WALKER M., OSUCH D. Assessment of greenhouse gas emissions in winter wheat farms using data envelopment analysis approach. Polish Journal of Environmental Studies, 24, 2197-2203, 2015.

24. NABAVI-PELESARAEI A., ABDI R., RAFIEE S. Energy use pattern and sensitivity analysis of energy inputs and economical models for peanut production in Iran. International Journal of Agriculture and Crop Sciences, $\mathbf{5}$ (19), 2193, 2013

25. OZKAN B., CEYLAN R.F., KIZILAY H. Comparison of energy inputs in glasshouse double crop (fall and summer crops) tomato production. Renewable Energy, 36, 1639, 2011.

26. HEIDARI M.D., OMID M. Energy use patterns and econometric models of major greenhouse vegetable productions in Iran. Energy, 36, 220, 2011.

27. CETIN B., VARDAR A. An economic analysis of energy requirements and input costs for tomato production in Turkey. Renewable Energy, 33, 428, 2008.

28. ESENGUN K., ERDAL G., GUNDUZ O., ERDAL H. An economic analysis and energy use in stake tomato production in Tokat province of Turkey. Renewable Energy, 32, 1873, 2007.

29. ABDI R., TAKI M., AKBARPOUR M. An analysis of energy input-output and emissions of greenhouse gases from agricultural productions. International Journal of Natural and Engineering Sciences, 6 (3), 73, 2012.

30. NALLEY L., POPP M., FORTIN C. The impact of reducing greenhouse gas emissions in crop agriculture: A spatial and production level analysis. Agricultural and Resource Economics Review, 40 (1), 63, 2011.

31. PISHGAR-KOMLEH S.H., OMID M., HEIDARI M.D. On the study of energy use and GHG (greenhouse gas) emissions in greenhouse cucumber production in Yazd province. Energy, 59, 63, 2013.

32. BANKER R., CHARNES A., COOPER W. Some models for estimating technical and scale inefficiencies in data envelopment analysis. Management Science, 30, 1078, 1984.

33. CHAUHAN N.S., MOHAPATRA P.K.J., PANDEY K.P. Improving energy productivity in paddy production through benchmarking-An application of data envelopment analysis. Energy Conversion and Management, 47, 1063, 2006.

34. MOHAMMADI A., RAFIEE S., MOHTASEBI S.S., MOUSAVI-AVVAL S.H., RAFIEE H. Energy efficiency improvement and input cost saving in kiwifruit production using Data Envelopment Analysis approach. Renewable Energy, 36, 2573, 2011.

35. SAEED M., KHAN N.A. Measurement of economic efficiency in agriculture of Peshawar district. Sarhad Journal of Agriculture, 23, 197-205, 2007.

36. JADIDI M.R., SABUNI M.S., HOMAYOUNIFAR M., MOHAMMADI A. Assessment of energy use pattern for tomato production in Iran: A case study from the Marand region. Research in Agricultural Engineering, 58, 50-56, 2012. 